\title{
Writing as a teaching learning technique: an example in chemistry (molar solution)
}

\author{
Adolfo E. Obaya, V., Carlos Osorio G., Yolanda Marina Vargas. \\ FES- Cuautitlán UNAM. Depto. Ciencias Químicas MADEMS Química. UNAM \\ Email: obaya@unam.mx
}

\section{Abstract}

Techniques are needed to train students in "writing to learn"., whose main goal is to "learn to write". This work aims to exemplify how writing can be a teaching learning technique in an example in Chemistry to develop a correct understanding of the preparation of molar solutions in the laboratory. It is essential that this is carried out in the classroom in a way that develops the reflective, analytical and cognitive skills of students. All this within an environment with safety measures at work
Keywords

Writing to learn, molar solutions, Chemistry, safety work

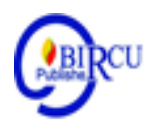

\section{Introduction}

In academic life, great deficiencies in written expression have been observed (Giammatteo and Obaya, 2018) so it is necessary to adopt techniques to train students and that their main intention is to "write to learn"., whose main objective is to "learn to write".

These techniques have been adopted to teach to achieve significant advances in learning through the writing of texts applied in various subjects (Obaya and Giammatteo, 2018).

This work aims to exemplify how writing can be a teaching-learning technique in an example in Chemistry to develop a correct understanding of the preparation of molar solutions in the laboratory.

\section{Theoretical Framework}

Since teaching and learning processes directly relate the task of writing to the construction and dissemination of (Molina-Natera, 2012) knowledge, it is essential that it be carried out in classrooms in a way that develops the reflective, analytical and cognitive skills of students.

The main advantages of getting students to write in any subject are:

1)Writing is a great way to evaluate students' knowledge.

2)Supporting students to express themselves with confidence can contribute to improved behavior and self-esteem.

3)Students, who write clearly, think clearly, and this helps them through the obstacles of adolescence.

4)Writing is power to understand and control their lives.

5)Writing is an essential skill for adult performance.

An alternative to developing these skills is by applying techniques that develop guided and supervised writing for the production of texts that support learning, such as the case of writing as a teaching learning technique, which is a strategy that develops the creativity of the student as it develops a criterion based on seven factors (Table 1) that determine the 
quality of a text (Spandel, 2008; Alvarez, 2010; Obaya, Vargas-Rodríguez, Giammatteo and Ruiz, 2019)

Table 1. Factors who determine the quality of a text

\begin{tabular}{|l|l|}
\hline \multicolumn{1}{|c|}{ Concept } & \multicolumn{1}{c|}{ Sense } \\
\hline 1) Ideas & the document is clear and focused on the main topic \\
\hline 2)Organization & the writer follows a logical and orderly sequence \\
\hline 3) Voice & the writer is expressive and hooks the reader \\
\hline $\begin{array}{l}\text { 4) Choice of } \\
\text { words }\end{array}$ & uses accurate and interesting words \\
\hline $\begin{array}{l}\text { 5) Fluidity of } \\
\text { utterances }\end{array}$ & text flows easily and with fluency \\
\hline 6)Conventions & Proper punctuation, grammar, spelling and paraphrase. \\
\hline 7)Presentation & care and quality of the text presentation \\
\hline
\end{tabular}

Based on the application of these seven criteria, both in the evaluation of texts and in the production of students, it is possible to significantly improve the quality of the writing. There are some activities that are constantly applied can be drivers of writing production in classrooms, such as allocating most of a class's time to writing, letting the same students choose their writing topics and formats, overseeing drafts to suggest improvements, writing together with students, and crafting conference spaces to feedback each other's work.

According to Steve (Peha, 2003) student-produced texts can be classified into three major types:

\section{Casual}

\section{Semi-formal}

Formal

The casual type refers to texts written for reading notes, lists, brainstorming, etc., where the style is informal, the main function is the organization of ideas and is usually not done to be evaluated. There are several types:

1) This process of "writing thought" is useful for knowing the mental processes of students and being able to differentiate the steps of a procedure they understand from those who do not. Taking notes can be effective for students when guided with techniques such as "Skeleton Notes", keynotes, note organization, use of the bent page for classification and periodic review of student notes. It is a fallacy to believe that the notes made by the teacher will be remembered by the students.

2) "Summary note" that applies in the following steps: a) The student should not take notes while the teacher explains, b) Stop the explanation every 5-10 min to resume important ideas on paper, c) Write them in their own words, d) Ask some students to read aloud their summary, e) Compare the versions and make relevant corrections if necessary and f) Continue with 5-10 minutes more of the class.

3) "Lists" can be helpful as they can be converted into interesting texts when you enter the questions What do you think? And why do you think about it? 
The semi-formal type refers to most texts that are reviewed in classrooms such as essays, summaries, reports, etc.; it is a more formal writing, but not strictly, that must communicate efficiently, usually addressed to colleagues or the teacher and whose function is to share information efficiently and should be evaluated for its content and not so much by the presentation, can be applied as follows:

1. Writing Response" in which students are encouraged to say what they think of a short prose that adheres to the six criteria of writing.

2. "Fiction with facts", in which students are invited to use creativity to write texts taking the identity of some important character for example historical or scientific.

The formal type of writing refers to the elaboration of scientific research, applications for employment, newspaper articles, essays for competitions, etc. The style is formal and must meet the expectations of the audience to whom it is addressed, usually aimed at audiences that are not known, is intended to achieve the proposed goals and must be evaluated by the seven criteria of writing.

1. Model 1: "Writing as Professionals", this involves assigning writing tasks where you are looking to have a formal work written as if you had the perspectives of a specialist.

2. Model 2: "Everything-what-you-can-write" from the point of view of... a scientist, a journalist, a naturalist, etc., giving the opportunity for the student to develop a formal document from the perspective of the chosen model.

3. Model 3: "Real Reasons for Real Writing", this type of writing is intended for the student to learn to write for a real purpose that is of particular interest and that he is attracted to investigate further, with the freedom to choose the format and type of narrative and then share it with his peers in order to feed back his work and improve it according to the seven criteria of writing. Other reasons for real writing, this type of writing is intended for the student to learn to write for a real purpose of which it is of particular interest and of which he is attracted to investigate more, with the freedom to choose the format and the type of narrative and then share it with his peers, however this model of writing gives the student the dexterity and skill of formal writing which will even help you delve into writing scientific articles (Sipayung, 2018).

\section{Research Method}

\subsection{Proposal for the Theme "Preparation of Molar Solutions in the Laboratory"}

Based on our teaching experience with High School and Freshmen students of the subject of Chemistry in the area Chemical-Biological Sciences, there are inconsistencies in the work of calculating and preparing Molar solutions of an acid, in the classroom regarding the work of the laboratory because students constantly incur the belief that when preparing $100 \mathrm{ml}$ of a $1 \mathrm{M}$ solution of $\mathrm{HCl}$, they have to mix $36.4 \mathrm{~g}$ of HCL with $100 \mathrm{ml}$ of water measured in a specimen, forgetting that they are prepared in the graduated flask and the importance of the capacity. Also consider the purity and density of the acid. As well as the security measures to be considered during their preparation.

Every employee is required to play an active role in setting plans, systems, processes, and goals to be achieved by the company. One way to achieve the effectiveness of a company is to foster and utilize human resources in order to produce a quality workforce, physically and mentally healthy, and have high skills to support the company's success. One important factor to consider is employee safety and health (Mora, Suharyanto and Yahya, 2020). 
Activities that guarantee the creation of safe working conditions are work safety and health, avoiding physical and mental disruption at work that aims to reduce and avoid the risk of work accidents (zero accident). In working, employees have the right to work safety and health

Work safety is the protection of employees from injuries caused by work-related accidents. While work healthy is a condition that is free from physical, mental, emotional or pain disorders caused by the work environment.

Organizational effectiveness is usually interpreted as the success achieved by an organization in its efforts to achieve predetermined goals. (Kuswati, 2019) Employees who have a high level of physical, mental and social health will be able to work with optimal deployment of personnel so that high performance can then increase productivity.

Employee performance is closely related to the results of one's work in an organization or company. The results of the work can involve quality, quantity, and timeliness, but performance evaluation in a company's organization is key in employee development. (Muhammad and Hidayat, R., 2019; Irfansyah, 2020).

Work safety is a safe or safe condition for sufferers, damage or loss at work. Safety risks are aspects of the work environment that can cause fires, bruises, sprains, fractures, impaired vision and hearing. Whereas work healthy shows a condition that is free from physical, mental emotional or pain disorders caused by the work environment. (Mangkunegara, 2009). Health risks are factors in the work environment that work beyond the specified time period.

\section{Discussion}

The ability of teachers to choose the right learning model is very likely for the creation of conducive and enjoyable learning conditions, so that the learning activities can take place effectively and efficiently (Bintang,Ruslan and Nasir, 2020)

Thus the learning model is a very decisive component for the creation of efficient conditions during the course of learning activities. No matter how well the design of the implementation of learning is made, there is very little chance that it will be able to succeed optimally to achieve the expected competency achievement if it is not supported by the selection of learning models. The behavior of the community, especially traditional communities, is reflected in their behavior utilizing the intellectual property of local people in the form of their traditional knowledge and biodiversity in their environment. Cultural practices related to health are partly claimed by "modern" knowledgeable people as one of the causes of poor health status of the local community.

To selecting and applying learning models, teachers must also have knowledge about students' critical thinking skills. Teaching the same material, the same methods, and the same assessment methods to all students is considered to produce the same results, this is not quite right, because even though all are treated the same, but who do the learning of individuals who have the ability to think critically different.

Critical thinking skills are the cognitive processes of students in analyzing systematically and specifically the problems faced, distinguishing these problems carefully and thoroughly, as well as identifying and reviewing information to plan problem solving strategies. The critical thinking is reflective thinking in depth in decision making and problem solving to analyze situations, evaluate arguments, and draw appropriate conclusions (Stobaugh,2013). People who are able to think critically are people who are able to infer what they know how to use information to solve problems, and are able to find relevant information sources. Based on the explanation above, critical thinking skills are the basic 
ability to solve problems. The application of critical thinking skills in learning is very important. The results showed that critical thinking in learning can improve student achievement (Jacob, 2012). In accordance with this opinion, Adeyemi (2012) states that critical thinking is very important in the learning process.

In order to help solve this problem, a writing-based activity is proposed as a teachinglearning technique in which the following points will be defined for the evaluation of the work:

1. Adopting Model 2 for formal writing ("Write as Professional"), each student will be asked to write a formal text.

2. The instruction is given as a case study:

"You have been named the Quality Chemist in a company's chemical reagent preparation laboratory and to initiate a standardization process, you need to write a Manual specifying the basics and procedures necessary for the preparation of hydrochloric acid $(\mathrm{HCl})$ molar solutions that are used in the Company clearly and concisely for the use of the laboratories in preparation of the solutions...Also you must establish the rules for work safety as the protection of employees from injuries caused by work-related accidents."

An organization can run effectively if management functions such as planning, organizing, motivation and supervision that are functioning well, and the supporting elements are available and fulfilling the requirements. One of the most important elements that can support the course of the company is human resources (employees). Human resources have an important role in determining the success of the company (Hartati, 2020).

Motivation will cause impetus to someone who causes him to do certain actions to meet their needs. So work motivation is a psychological condition that encourages workers to make an effort to produce goods or services so that a goal can be achieved.

The factors that affect a person's performance are very complex (Soelaiman, 2007).: which include; training and work experience, education, personality attitudes, organizational leaders, social conditions, individual needs, physical condition of the workplace, abilities, work motivation and so on. Ability and motivation are factors that interact with performance.

A person's abilities can be determined by skills and knowledge, whereas skills can be influenced by skills. Personality and knowledge can be influenced by education, training experience and interests. Basically motivation can be sourced from a person or often known as internal motivation and can also be sourced from outside oneself or also called external motivation. Empirically and internally motivated motivation can improve performance (Shintya, Ervina, and Donna Mundung., 2015). Several other researchers have in common that empirical motivation has a strong and positive influence on the formation of employee performance (Karyono, 2018). Employee performance is also influenced by competency factors, this is in line with the results of previous studies that empirically prove that competence has a positive and significant effect on performance (Mukhtar, 2018).

In addition, the provision of compensation is one of the important factors in influencing employee performance is the existence of fair and equitable compensation. Some of the results of previous studies have empirically confirmed that compensation has a positive and significant effect on employee performance (Darma et al, 2018).

3. The evaluation criteria for the document shall be as follows:

A. Ideas, that the document is clear and focused on the main topic. 
- What is the author's purpose, how, and for what purpose?

- What secondary or supportive aspects does the author use to support the main idea?

- How does the author communicate the subject?

B. Organization, may the author follow a logical and orderly sequence,

- How does the author group themes or ideas?

- In what order does the author present the information or events to be developed?

- What methods does the author use in respect of materials, instrumentation, grinding calculations, processes, control and evaluation in the laboratory?

C. Voice, the author must be expressive and interest the reader,

- How does the author show his personality in writing?

- How does the author convey his emotions?

- What makes reading the writing a meaningful experience??

D. Word choice, uses precise and interesting words,

- What are the most relevant words that the author uses, and how do these words support the author's purpose?

- Do you maintain a homogeneous terminology and use the symbology of chemical solution?

- Is a figurative language or other techniques used to keep the reader interested?

- What words create a living image in the reader's mind?

E. Fluidity of utterances, text flows easily and with rhythm or fluency;

- What different types and lengths of sentences are used by the writer?

- Can the writing be read aloud without problems and without losing expression?

- In what different ways does the author begin and end the sentences?

F. Conventions, proper score, gram-like, spelling and paraphrase,

- How the author does correctly uses capital letters, punctuation marks, and other conventions?

- Does the author use italic, black or underline to highlight the essential contents?

- What is the presentation of the writing like?

G. Impersonal writing. To mention to the student that in the writing of academic texts and seriousness the grammar form of the first person (I, We), using the personal pronoun is avoided.

A maximum score of 5 and a minimum of 1 will be assigned in each of the six criteria for evaluating the written work presented by each student, which will be added to calculate the total score. We suggested this punctuation with base our experience teaching in the subject Solutions for Experimental Laboratory.

\section{Conclusion}

Freshmen and High School students must acquire generic verbal and written communication skills for their professional performance, which allows them to gain greater, qualifications to access the working market. These skills can be developed by writing as a 
teaching learning technique; in this case, describing a chemical process related to the preparation of molar solutions in a laboratory.

Although this technique can be applied generally to any subject taught in university education, it is considered doubly beneficial to use it in the chemistry careers, since it is noted that most students who opt for this type of careers often do not have highly developed verbal and/or written communication skills (Morales, A., Obaya, A. Montaño, C. and VargasRodríguez, Y., 2020).Teaching is not to transfer knowledge but to create possibilities for its production or construction, but in either case it is essential to capture in oral or written language the knowledge to be produced, built or transferred.

Language is not a set of facts to be learned but a medium for expressing thoughts, feelings in communication with other people. It means that as the principal medium of communication, (Norrish,1983): it plays an important and indispensable role in all aspects of human life, such as friendship, agreement, laws, convention, marriages, scientific papers and others.and specially in the writing (Hariati, 2020)

\section{References}

Adeyemi, S.B. (2012). "Developing Critical Thinking Skills in Students: A Mandate for Higher Education in Nigeria. European Journal of Educational Research. 1 (2): 155161.

Álvarez O. B.. (2010). Evaluación del conocimiento estratégico de los alumnos a través de tareas auténticas de escritura. Avances en Psicología Latinoamericana, vol. 28, núm. 2, diciembre, 251-264,.

Bintang, N.S., Ruslan, D. and Nasir, M. (2020) The Effect of Learning Model and Critical Thinking on Entrepreneurship Learning Outcomes of 11th Grade Student in 7 Vocational School Academic Year 2019/2020 Britain International of Humanties and Social Sciences (BIoHS) Journal 2685-1989(Print) Vol. 2, No. 1, February 15-25

Darma, P. S. et al. (2018) 'The Effect of Compensation on Satisfaction and Employees', Management and Economics Journal, 1(February), pp. 69-77. doi: 10.18860/mecj.v1i1.4524.

Iron Mountain Public Schools. (17 february 2015). "The Six Traits Professional Development Model". www.imschools.org/images/files/menufiles/Overview6Traits.pdf

Giammatteo, L and Obaya, A. (2018) "Assessing Chemistry Laboratory Skills Through a Competency based Approach in High School Chemistry Course" Science Education International i Volume 29! Issue 2 103-109

Hariati, P. (2020) Improving Students' Vocabulary Mastery through Teaching Real Object Budapest International Research and Critics in Linguistics and Education (BirLE) Journal Volume 3, No 2, 740-74

Hartati, T. (2020) Analysis of Influence of Motivation, Competence, Compensation toward Performance of Employee Budapest International Research and Critics Institute-Journal (BIRCI-Journal) Volume 3, No 2, May 1031-1038

Irfansyah. (2020). The Duties and Functions Performance of Aceh Human Resources Improvement Institutions inScholarship Study Program Implementation in Aceh Government. Britain International of Humanities and Social Sciences Journal: 160-165

Jacob, S.M. (2012). "Mathematical Achievement and Critical Thinking Skills in Asynchronous Discussion Forums". Procedia Social and Behavioral Sciences. 31: 800804. 
Karyono, O. (2018) 'Faktor determinan motivasi dan disiplin kerja terhadap kinerja pegawai serta dampaknya pada mutu pelayanan pada dinas pemuda, olahraga, budaya dan pariwisata (disporabudpar) kabupaten majalengka', Proceeding STIMA, 1(1), 348-359. Available at: https://scholar.google.com/citations?user=yUuxCLUAAAAJ\&hl=en\#d=gs_md_cita$\mathrm{d} \& \mathrm{u}=\% 2 \mathrm{Fcitations} \% 3 \mathrm{Fview}$ _op\%3Dview_citation\%26hl\%3Den\%26user\%3DyUuxCL 1038UAAAAJ\%26citation_for_view\%3DyUuxCLUAAAAJ\%3ATyk4Ss8FVUC\%26tzom\%3D-420.

Kuswati, Y. (2019). Motivation Role in Improving Work Effectiveness. Budapest International Research and Critics Institute (BIRCI-Journal) : Humanities and Social Sciences, 2(4); 281-288.

Mangkunegara, Anwar Prabu, (2009), Manajemen Sumber Daya Manusia Perusahaan, Bandung: PT. Remaja Rosdakarya.

Molina-Natera, V. (2012). Escritura a través del currículo en Colombia:situación actual y desafíos. Magis, Revista Internacional de Investigación en Educación, vol. 5, núm. 10, julio-diciembre, 93-108.

Mora, Z., Suharyanto, A. and Yahya, M. (2020) Effect of Work Safety and Work Healthy Towards Employee's Productivity in PT. Sisirau Aceh Tamiang. Budapest International Research and Critics Institute-Journal (BIRCI-Journa 1) Volume 3, No 2, , 753-760

Morales, A., Obaya, A. Montaño, C. and Vargas-Rodríguez, Y. (2020) Exploratory Assessment of Strategy for Learning Redox Reactions in High SchooL International Journal of Education (IJE) Vol.8, No.1, March 23 - 37

Muhammad and Hidayat, R. (2019). The Relationship between the Transformational Leadership Style of Madrasah Head and Work Discipline with the Performance of Teachers atMTsN Lima Puluh Batu Bara. Britain International of Linguistics, Arts and Education Sciences (BIoLAE) Journal, 175-182.

Mukhtar, A. (2018) 'The Effect Of Competence And Organization Culture To Work Satisfaction And Employee Performance Of Sharia Banks In Makassar City', International Journal of Scientific \& Technology Research, 7(10).

Obaya, A. and Giammatteo, L. (2018) "The 2030 Agenda for Sustainable Development: How to Get Students Involved?" World Journal of Educational Research Vol. 5, No. 4, 358367

Obaya, A., Vargas-Rodríguez, Y., Giammatteo, L. and Ruiz, C. (2019) The Role of Educational Research In Teaching Chemistry International Journal of Development Research Vol. 09, Issue, 01,.25253-25257, January.

Peha, S. (17 February 2003). Writing Across the Curriculum. http://www.ttms.org/PDFs/06\%20Writing\%20Across\%20the\%20Curriculum\%20v001 $\% 20 \% 28$ Full\%29.pdf

Shadrina, N., Ruslan, D, and Nasir, M. (2020) The Effect of Learning Model and Critical Thinking on Entrepreneurship Learning Outcomes of 11th Grade

Student in 7 Vocational School Academic Year 2019/2020 Britain International of Humanties and Social Sciences (BIoHS) Journal 2685-1989(Print) Vol. 2, No. 1, February,: 15-25 
Shintya Ervina Donna Mundung., S. P. (2015) 'The influence of Extrinsic and Intrinsic Motivation on Employee', Journal EMBA, 3(2), pp. 25-35.

Sipayung, Rohdearni Wati. (2018). Improving Students' Achievement in Reading Descriptive Text through Reciprocal Teaching Strategy. Budapest International Research and Critics in Linguistics and Education (BirLE) Journal, 29-48.

Soelaiman, S. (2007) Manajemen Kinerja : Langkah Efektif untuk Membangun, Mengendalikan dan Evaluasi Kerja. Jakarta: Intermedia Personalia Utama.

Spandel, V. (2008). Creating Writers Through 6-Trait Writing Assessment and Instruction (5th Edition): Allyn \& Bacon.USA

Stobaugh, R. (2013). Assesing Critical Thinking in Middle and High Schools: Meeting the Common Core. New York: Routledge.

Zulkarnen Mora, Suharyanto, A. and Yahya, M. (2020) Effect of Work Safety and Work Healthy Towards Employee's Productivity in PT. Sisirau Aceh Tamiang Budapest International Research and Critics Institute-Journal (BIRCI-Journal Volume 3, No 2,: 753-760 